\title{
AMPHIBIANS
}

\section{RE-EVALUATION OF RELATIVE ABUNDANCE OF FIVE FROG AND TOAD SPECIES IN RIDING MOUNTAIN NATIONAL PARK, MANITOBA}

Ken Kingdon

Riding Mountain National Park, Wasagaming, MB, R0J 1NO. E-mail: <ken.kingdon@pc.gc.ca>

\section{Introduction}

My personal observations have suggested that there may have been several changes in the frog and toad populations and their distribution within Riding Mountain National Park (RMNP), MB. A 1974 checklist identified the following species as occurring in RMNP: Canadian toad (Anaxyrus hemiophrys), gray treefrog (Hyla versicolor), boreal chorus frog (Pseudacris maculata), wood frog (Lithobates sylvaticus), and northern leopard frog (Lithobates pipiens). ${ }^{1}$ According to the Canadian Amphibian and Reptile Conservation Network (CARCNET), this is the generally expected distribution of frogs and toads for the region. ${ }^{2}$ However, significant worldwide changes in amphibian populations have been noted for at least 35 years, and regionally, the northern leopard frog has declined in large areas of its original range in North America. ${ }^{3,4}$

The objective of this study was to compare changes in abundance of frog and toad species in RMNP to two previous estimates of relative abundance made in 1974 and $1987 .^{1,5}$ Due to large perceived changes in northern leopard frog and gray treefrog populations, special emphasis was placed on changes in these two species. On the other hand, no special measures were made to assess the
Canadian toad, as it was believed to be extirpated at least 20 years before the current study. A brief comparison to changes in amphibian populations in other areas around RMNP was also made.

\section{Materials and Methods}

Historic information on frog relative densities was gleaned from the RMNP library. To assess current relative abundance of frogs inside RMNP, visual and calling surveys were carried out in a manner set out by Kendell, ${ }^{4}$ and the result compared with historic information. ${ }^{1,5}$ The survey period was from April to October 2010, which encompassed breeding/ reproduction periods, metamorphosis, and movement of frogs to their wintering sites in the fall. Surveys were conducted at different times of day to permit detection during both visual surveys and calling surveys.

Visual Surveys: Two different types of visual surveys were conducted. First, seven permanent routes were established (Fig. 1) to survey areas where leopard frogs had previously been detected in the last 15 years. ${ }^{6,7}$ Each of the seven permanent routes was surveyed at least five times, with three of the most accessible routes surveyed nine times. Second, 30 trails/routes were also 

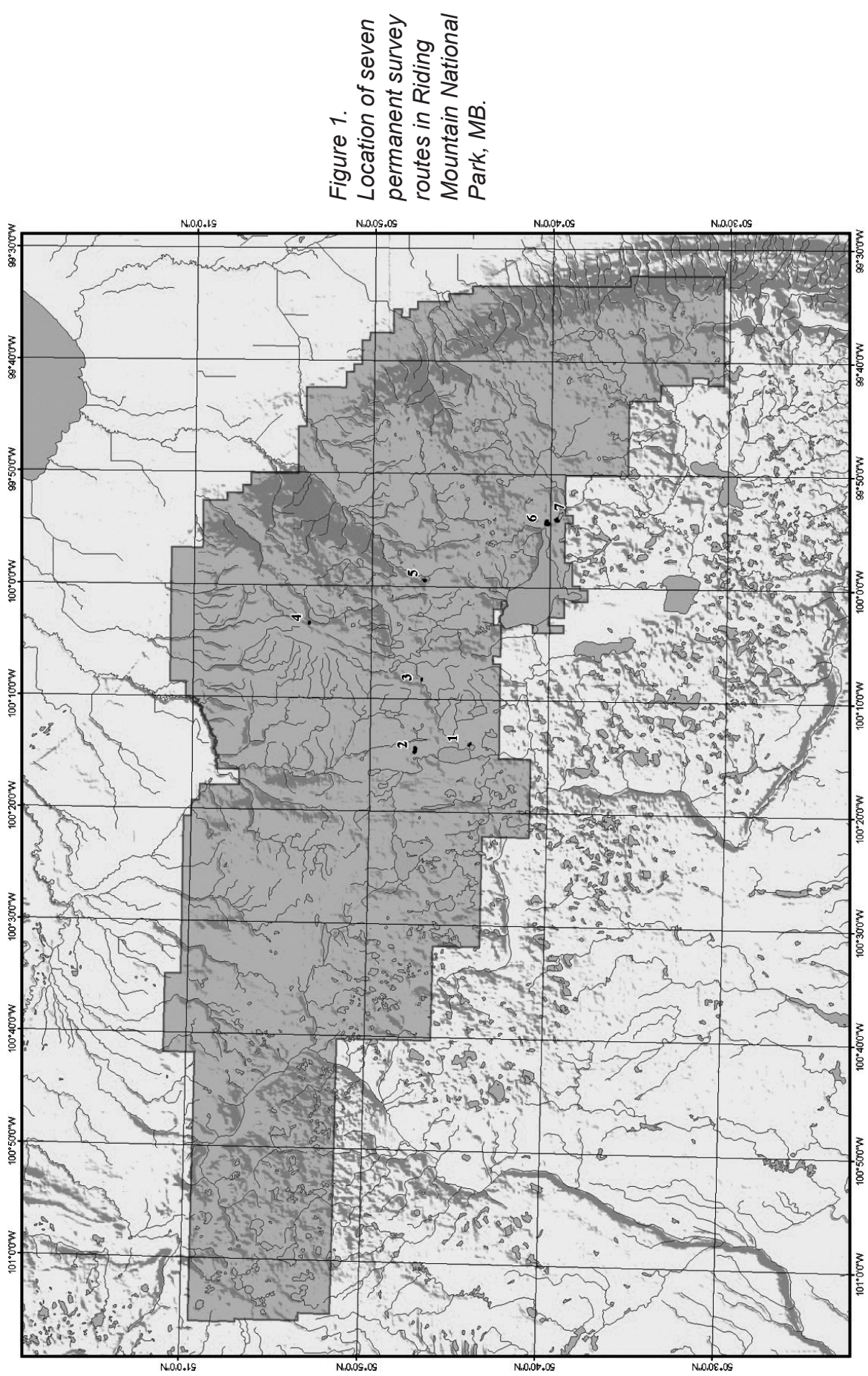
surveyed opportunistically during the daytime in July, August, and September using the same method.

Surveyors moved slowly around the perimeter of each pond (in the case of permanent routes) or along trails (in the case of opportunistic routes) searching approximately $1 \mathrm{~m}$ to each side or in front for frogs visible without moving debris. Both the pond edge and upland areas were surveyed. All egg masses, tadpoles, young-of-the-year, and adults observed were recorded on datasheets. To increase the ability to spot frogs, visual surveys were conducted during the warmest period of the day, usually after noon, when amphibian activity was expected to be greatest. ${ }^{4}$ Travel speed was adjusted slightly depending on the terrain so that surveyors were confident that all amphibians in sight were observed. The date, start time, end time, air temperature, transect length, and pond location were recorded for each survey. The survey transect length was calculated by recording the route on a hand-held GPS unit (Garmin $60 \mathrm{Cx}$ ). The UTM coordinates were recorded for each pond/route.

Call Surveys: 2010 nocturnal call surveys were also conducted as outlined by Kendell. ${ }^{4}$ On each of the permanent routes, an estimate of the abundance of each calling species heard was recorded during a 3-min survey period. The abundance of calling frogs was estimated using four calling codes: no males calling was coded as " 0 ," individual males calling with no overlap were coded as " 1 ," individual males calling with some overlap of calls were coded as " 2 ," and a full chorus, with no discernable individual calls, was coded as "3." The surveys were conducted at least a half hour after sunset and ended before midnight. The call surveys were conducted at several different times during the spring to correspond with expected calling periods of wood frog (April, early May); boreal chorus frog, leopard frog, and Canadian toad (May); and gray treefrog (June). It is recognized that species' calling periods overlap, but the survey was designed to ensure maximum potential to record presence of all five expected species. Call rates were also recorded at other times of the day, and also along opportunistic survey routes where applicable.

\section{Results}

Historic Information: The review of the historic information provided a baseline of relative abundance of frog and toad species. While much of the information on how the lists were developed was missing, the definitions used to establish densities were useful, and these definitions were also used to compare the 2010 results to previous surveys. Results of research into historic abundance are presented in Table 1 , as a tabular comparison of a previous checklist (1974) and survey (1987). ${ }^{1,5}$

2010 Relative Abundance Surveys: The average length of the permanent surveys was $1.16 \mathrm{~km}$, and the surveyor's average survey speed was $2.06 \mathrm{~km} / \mathrm{h}$, while the average length of the opportunistic surveys was $5.77 \mathrm{~km}$ and the average survey speed was $4.89 \mathrm{~km} / \mathrm{h}$. Wood frogs, boreal chorus frogs, and gray treefrogs were detected at least once on all seven permanent routes, while northern leopard frogs were found on three of the routes, and Canadian toads on 0 routes (Table $2)$. Gray treefrogs were detected on nearly one-third of the surveys, providing evidence of a large increase in the range and population of this species within RMNP.

Visual sightings of metamorphosed individuals including young-of-the-year, sub-adults, or adults of wood frogs and northern leopard frogs were compared for the seven permanent routes (Table 
Table 1. Results of frog and toad abundance from 1974, 1987, and 2010, with (a) a comparison of 2010 survey results to previous 1974 checklist/1987 survey, and (b) newly developed abundance definitions.

(a) Comparison of survey results

\begin{tabular}{|l|l|l|l|l|l|}
\hline Species & $\begin{array}{l}1974 \\
\text { abundance }^{\mathrm{a}}\end{array}$ & $\begin{array}{l}\text { 2010 results } \\
\text { using 1974 } \\
\text { definitions }\end{array}$ & $\begin{array}{l}1987 \\
\text { abundance }^{\mathrm{b}}\end{array}$ & $\begin{array}{l}2010 \text { results } \\
\text { using 1987 } \\
\text { definitions }\end{array}$ & $\begin{array}{l}\text { 2010 results } \\
\text { using new } \\
\text { definitions }^{\mathrm{c}}\end{array}$ \\
\hline Canadian toad & Common & $?$ & Rare & $?$ & Extirpated $^{\text {? }}$ \\
\hline Gray treefrog & Rare & Common & Uncommon & Common & Common \\
\hline Boreal chorus frog & Abundant & Abundant & Common & Common & Abundant \\
\hline Wood frog & Common & Abundant & Common & Common & Abundant \\
\hline $\begin{array}{l}\text { Northern leopard } \\
\text { frog }\end{array}$ & Abundant & Uncommon & Common & Uncommon & Uncommon \\
\hline
\end{tabular}

(b) Definitions of frog and toad abundance

\begin{tabular}{|c|c|c|c|}
\hline Term & a1974 definition & b1987 definition & c2010 definition \\
\hline Abundant & $\begin{array}{l}\text { Seen on almost all } \\
\text { visits to the preferred } \\
\text { habitat during the proper } \\
\text { seasons. }\end{array}$ & & $\begin{array}{l}\text { Seen or heard daily on all } \\
\text { visits to appropriate habitat } \\
\text { during the appropriate } \\
\text { seasons. }\end{array}$ \\
\hline Common & $\begin{array}{l}\text { Seen on a majority of } \\
\text { visits to the preferred } \\
\text { habitat during the proper } \\
\text { seasons. }\end{array}$ & $\begin{array}{l}\text { Likely to be seen daily in the } \\
\text { park in appropriate habitat } \\
\text { during the appropriate } \\
\text { season. }\end{array}$ & $\begin{array}{l}\text { Seen or heard on greater } \\
\text { than } 50 \% \text { of visits to } \\
\text { appropriate habitat during } \\
\text { the appropriate seasons. }\end{array}$ \\
\hline Uncommon & $\begin{array}{l}\text { Present every year in the } \\
\text { preferred habitat during } \\
\text { the proper seasons, but } \\
\text { occurs in low numbers } \\
\text { and often difficult to } \\
\text { find. }\end{array}$ & $\begin{array}{l}\text { Sparsely distributed. May } \\
\text { be seen in appropriate } \\
\text { habitat during the } \\
\text { appropriate season but } \\
\text { not on a daily basis. }\end{array}$ & $\begin{array}{l}\text { Seen or heard on }<50 \% \text {, } \\
\text { but }>10 \% \text {, of visits to } \\
\text { appropriate habitat during } \\
\text { the appropriate seasons; } \\
\text { occurs in low numbers, } \\
\text { exhibits sparse distribution. }\end{array}$ \\
\hline Rare & $\begin{array}{l}\text { Present every year but in } \\
\text { low numbers at varying } \\
\text { locations. }\end{array}$ & $\begin{array}{l}\text { Present in low numbers } \\
\text { and/or sparsely distributed. } \\
\text { May be seen only } \\
\text { occasionally. }\end{array}$ & $\begin{array}{l}\text { Believed to be present in } \\
\text { the park, seen or heard on } \\
<10 \% \text { of visits to appropriate } \\
\text { habitat during the appropriate } \\
\text { seasons. Detected in low } \\
\text { numbers and very limited } \\
\text { distribution. Not necessarily } \\
\text { seen or heard every year. }\end{array}$ \\
\hline Extirpated & & & $\begin{array}{l}\text { No longer found in the } \\
\text { park. }\end{array}$ \\
\hline
\end{tabular}


3). On these seven routes, a total of 315 wood frogs were observed, compared to only seven leopard frogs, suggesting that wood frogs were much more abundant than leopard frogs.

On the opportunistic routes, wood frogs were also the most abundant species observed, followed in order of decreasing abundance by boreal chorus frogs, leopard frogs, and gray treefrogs (Table 4). No Canadian toads were observed. Tables 2 and 4 show consistent detection rates for wood frogs and leopard frogs on both permanent and opportunistic survey routes, while there was a decrease in the detection rate of boreal chorus frogs and gray treefrogs on the opportunistic surveys compared to the permanent routes.

\section{Discussion}

Using the methodologies outlined above, it is impossible to make definitive statements about the relative abundance or true abundance of amphibians in RMNP. As discussed in previous studies, there are several weaknesses related to a survey that combines both qualitative and quantitative data, particularly one in which the survey areas were nonrandomly selected, and the entire area was not surveyed. ${ }^{8,9}$ In addition, the majority of the surveys were conducted in a relatively haphazard manner, which allows the development of a species list, but makes replication for monitoring purposes impossible. ${ }^{9}$

However, there is little doubt that there have been changes in the frog and toad populations within RMNP. When comparing the 2010 results to those from 1974 and 1987, a definite decline in both northern leopard frogs and Canadian toads is evident, while gray treefrog populations have increased. To examine the changes further, the 2010 survey results were compared to the 1974 checklist and the 1987 survey results, using the definitions of abundance used in 1974 and 1987, respectively (Table 2).

As comparisons between the three surveys were conducted, it became apparent that a more quantitative set of definitions was needed. A new set of definitions for frog and toad abundance was created, based on some of the previous definitions used in the 1974 checklist and the 1987 amphibian survey. Even these new definitions create some problems with interpretation of what exactly is meant by "in appropriate habitat in the appropriate season." Thus, while all of RMNP's ecosystems are generally considered to support all expected species (i.e. almost all areas inside the park could be considered appropriate habitat for all species), the appropriate season is more difficult to determine. Enhancement of the definition of "appropriate season" is recommended, based on life cycle/ behavioural characteristics of each species (Table 5). ${ }^{2,10}$ Table 5 identifies the recommended survey technique and appropriate season by month for each species.

This refinement of the definition of "appropriate season" is also useful as it recognizes differences among the species which affect numbers detected. Gray treefrogs and boreal chorus frogs are difficult to see in visual surveys. Wood frogs and northern leopard frogs are much more terrestrial and larger, making visual observations easier in July and August. Nocturnal call surveys are useful for estimating abundance of wood frogs, but quieter, less vocal species such as leopard frogs are not as effectively found by their calls. ${ }^{4}$ Detecting egg masses is also difficult for some species, including gray treefrogs. Thus, an effort was made to determine the abundance of each species by using the appropriate survey methodology. Climate change may 
Table 2. Number of surveys of the seven permanent routes on which each species was observed. In total, 48 surveys were conducted in 2010.

\begin{tabular}{|l|c|}
\hline Species & No. of surveys (\% of all surveys) \\
\hline Canadian toad & $0(0)$ \\
\hline Gray treefrog & $15(31.3)$ \\
\hline Boreal chorus frog & $20(41.7)$ \\
\hline Wood frog & $28(58.3)$ \\
\hline Northern leopard frog & $6(12.5)$ \\
\hline
\end{tabular}

Table 3. Comparison of survey results on seven permanent routes for wood frog and northern leopard frog. In total, 48 surveys were conducted.

\begin{tabular}{|l|l|l|}
\hline & Wood frog & Northern leopard frog \\
\hline Total no. of individuals observed & 315 & 7 \\
\hline No. of routes observed (\% of all routes) & $25(52.1)$ & $6(12.5)$ \\
\hline No. of individuals observed/hour & 11.62 & 0.26 \\
\hline No. of individuals observed/km & 5.64 & 0.13 \\
\hline
\end{tabular}

Table 4. Comparison of survey results on $\mathbf{3 0}$ opportunistic survey routes for each species observed.

\begin{tabular}{|l|l|l|l|l|l|}
\hline & $\begin{array}{l}\text { Canadian } \\
\text { toad }\end{array}$ & $\begin{array}{l}\text { Gray } \\
\text { treefrog }\end{array}$ & $\begin{array}{l}\text { Boreal } \\
\text { chorus frog }\end{array}$ & Wood frog & $\begin{array}{l}\text { Northern } \\
\text { leopard frog }\end{array}$ \\
\hline No. of individuals & 0 & 3 & 33 & 253 & 23 \\
\hline$\%$ of routes detected & 0 & 6.7 & 33.0 & 53.3 & 10 \\
\hline No. of individuals/hour & 0 & 0.09 & 0.93 & 7.13 & 0.65 \\
\hline No. of individuals/km & 0 & 0.02 & 0.19 & 1.46 & 0.13 \\
\hline
\end{tabular}

require further adjustment of "appropriate season" for species where the onset of the breeding season is determined primarily by temperature rather than by photoperiod.

As stated, gray treefrogs were detected on all seven permanent routes during the call surveys. According to both the 1974 checklist and previous work, gray treefrogs were present, but considered uncommon in RMNP. ${ }^{1,10}$ According to published maps, treefrogs appeared to be confined to the eastern portion of the Park, and were still considered to be uncommon in 1987. 5,10,11 I first observed gray treefrogs inside RMNP in 1995, in the town of Wasagaming within the central portion of the park, an area at that time considered to be outside the normal range of this species. Since that time, I have detected gray treefrogs in all regions of the park, including in the highest elevations of the eastern portion and in the driest prairie regions. They have also been found in the most westerly areas of the park, approximately $50 \mathrm{~km}$ beyond the historic range of the species. This includes a dead specimen that I discovered in a cabin at the Sugarloaf trailhead on 28 October 2010, near the western boundary of RMNP. Taylor 
also recorded a possible change in the distribution of gray treefrogs in western Manitoba outside the park, although he indicated that this apparent range extension may be a function of historic under-sampling of these areas. ${ }^{12,13}$ However, this is not the case in RMNP, which was well surveyed in the past, yet has shown an increase in population density and distribution from the 1987 survey to the 2010 survey.

The comparison of detection rates of frog species between permanent routes and the opportunistic routes provides some food for thought. Boreal chorus frogs may have been observed less frequently on the opportunistic surveys when compared to the permanent routes due to the relatively faster average speed during the former, making it difficult to observe the small frogs.

As well, the detection rates reported in Table 4 for northern leopard frogs and gray treefrogs are misleading. It would appear that the opportunistic surveys were better at finding leopard frogs, and that these frogs are more common than the treefrogs. It should be noted, however, that 20 of the 23 leopard frog sightings were from one site that I visited as a direct consequence of park staff observations of this group of frogs. As well, as stated above, gray treefrogs are extremely difficult to detect when they are not calling. Most opportunistic surveys were done later in the summer, after the breeding period, and thus detections were primarily visual observations. The only gray treefrog detections were of calling males in August, outside the normal breeding season.

Given the analysis above, there have been definite declines in two species, namely the Canadian toad and the northern leopard frog. Further analysis was done to compare leopard frog and wood frog visual detections on both the seven permanent routes and the opportunistic surveys. As previously stated, the permanent routes were selected based on relatively recent observations of leopard frogs in the immediate area. Therefore, even though the routes were biased towards leopard frog detections, the results in Table 3 , supported by the data presented in Table 4 , indicate that leopard frogs are currently found less often than wood frogs. Thus, there is solid evidence that the leopard frog population has declined both in abundance relative to wood frogs and, based on the 1974 checklist and 1987 survey definitions, also in actual numbers. The other alarming note is the apparent extirpation of Canadian toads from the park since 1987.

Several possible reasons could account for these changes in leopard frog and Canadian toad populations. Collins and the CARCNET website provide good reviews of possible causes of frog and toad declines around the world, ranging from climate change, changes to water quality, acid rain, and increase in ultraviolet light, to habitat destruction, competition, commercial harvesting, and disease. ${ }^{2,3}$ Several of the expected causes do not appear to apply to RMNP. For example, commercial harvesting has never been allowed in the park. Research on the effects of the reintroduction of beavers on the park ecosystem has shown that the area of park surface water has actually increased between 1964 and 1996 due to impounded water, suggesting that habitat loss is not a key factor in frog declines. ${ }^{14}$

Whenever discussion occurs regarding fluctuations in populations, climate change is often highlighted as a possible reason for the differences. Amphibians may be particularly sensitive to longterm changes in the weather. It is too 
Table 5. Recommended survey time and method for monitoring five species of frogs and toads in Riding Mountain National Park, MB.

\begin{tabular}{|c|c|c|c|c|c|c|}
\hline & April & May & June & July & August & September \\
\hline $\begin{array}{l}\text { Canadian } \\
\text { toad }\end{array}$ & & & $\begin{array}{l}\text { Nocturnal } \\
\text { call survey }\end{array}$ & $\begin{array}{l}\text { Visual } \\
\text { search for } \\
\text { tadpoles }\end{array}$ & & \\
\hline $\begin{array}{l}\text { Gray } \\
\text { treefrog }\end{array}$ & & $\begin{array}{l}\text { Nocturnal } \\
\text { call survey } \\
\text { (mid- to end } \\
\text { of month) }\end{array}$ & $\begin{array}{l}\text { Nocturnal } \\
\text { call survey }\end{array}$ & $\begin{array}{l}\text { Nocturnal } \\
\text { call survey, } \\
\text { visual } \\
\text { search for } \\
\text { tadpoles }\end{array}$ & $\begin{array}{l}\text { Visual } \\
\text { search for } \\
\text { tadpoles }\end{array}$ & \\
\hline $\begin{array}{l}\text { Boreal } \\
\text { chorus frog }\end{array}$ & $\begin{array}{l}\text { Nocturnal } \\
\text { call survey }\end{array}$ & $\begin{array}{l}\text { Nocturnal } \\
\text { call survey }\end{array}$ & $\begin{array}{l}\text { Visual } \\
\text { search for } \\
\text { tadpoles }\end{array}$ & $\begin{array}{l}\text { Visual } \\
\text { search for } \\
\text { tadpoles \& } \\
\text { dispersing } \\
\text { young of } \\
\text { year }\end{array}$ & $\begin{array}{l}\text { Visual } \\
\text { search for } \\
\text { dispersing } \\
\text { frogs to } \\
\text { over- } \\
\text { wintering } \\
\text { areas }\end{array}$ & \\
\hline Wood frog & $\begin{array}{l}\text { Nocturnal } \\
\text { call survey }\end{array}$ & $\begin{array}{l}\text { Nocturnal } \\
\text { call survey }\end{array}$ & $\begin{array}{l}\text { Visual } \\
\text { search for } \\
\text { tadpoles }\end{array}$ & $\begin{array}{l}\text { Visual } \\
\text { search for } \\
\text { tadpoles } \\
\text { dispersing } \\
\text { young of } \\
\text { year, \& } \\
\text { adults }\end{array}$ & $\begin{array}{l}\text { Visual } \\
\text { search for } \\
\text { dispersing } \\
\text { frogs to } \\
\text { over- } \\
\text { wintering } \\
\text { areas }\end{array}$ & \\
\hline $\begin{array}{l}\text { Northern } \\
\text { leopard } \\
\text { frog }\end{array}$ & $\begin{array}{l}\text { Incidental } \\
\text { nocturnal } \\
\text { call survey } \\
\text { (conducted } \\
\text { while } \\
\text { surveying } \\
\text { other } \\
\text { species) }\end{array}$ & $\begin{array}{l}\text { Incidental } \\
\text { nocturnal } \\
\text { call survey } \\
\text { (conducted } \\
\text { while } \\
\text { surveying } \\
\text { other } \\
\text { species) }\end{array}$ & & $\begin{array}{l}\text { Visual } \\
\text { search for } \\
\text { tadpoles }\end{array}$ & $\begin{array}{l}\text { Visual } \\
\text { search for } \\
\text { dispersing } \\
\text { young of } \\
\text { year \& } \\
\text { adults }\end{array}$ & $\begin{array}{l}\text { Visual } \\
\text { search for } \\
\text { dispersing } \\
\text { frogs to } \\
\text { over- } \\
\text { wintering } \\
\text { areas }\end{array}$ \\
\hline
\end{tabular}

early to determine whether the changes observed in this study can be attributed to a warming climate. However, as in most areas on the prairies, some changes in weather have been noticed in the Riding Mountain area. In particular, weather data from the Environment Canada weather station in Wasagaming does show a slight overall warming in annual temperature since the $1970 \mathrm{~s}^{15}$ As well, the mean annual minimal temperature also appears to be increasing, indicating a general warming trend. These changes could possibly play a role in the decline of leopard frogs and the disappearance of the toads, as warmer temperatures could result in ponds drying up prior to successful metamorphosis of tadpoles, and thus increased mortality.

The slight increase in mean annual temperatures and an increase in the coldest winter temperature could provide one explanation for the apparent increase of gray treefrogs in the park. This species mates at warmer temperatures and 
later in the spring than other resident frogs and toads, and an increase in summer temperatures may provide more opportunities for breeding. ${ }^{16}$ The warmer annual minimal temperatures may also mean that more gray treefrogs overwinter successfully, particularly during low-snow years when severe cold would normally penetrate into the leaf litter. Relative humidity and elevation have been suggested as possible limiting factors in the distribution of gray treefrogs. ${ }^{10,12}$ However, as stated, this species has now been heard in all areas of the park, including both the highest elevations and the driest areas. This may indicate that the distribution of gray treefrogs is no longer limited by either of these historic factors due to changes in local weather. Whatever the reasons for the changes in RMNP frog and toad populations, their beginnings can likely be dated back to the 1970s, based on much earlier observations near the park and my own subsequent observations. Bird reported that historically, leopard frog densities reached highs of 194 individuals per acre in the Parkland region. ${ }^{17}$ His field station was located near Birtle, Manitoba, approximately $50 \mathrm{~km}$ from the RMNP boundary. Densities at the field station are expected to have been similar to the surrounding aspen parkland, including similar habitat inside the park.

Anecdotally, as a child raised on a farm in the 1970s in an area approximately 50 $\mathrm{km}$ south of the park, I noted a sudden decline in leopard frogs. By 1980, they were rarely found on our farm, while a decade earlier, they had been abundant. They have since become extirpated from the farm. These observations coincide with observations in Alberta, where leopard frogs declined suddenly in the late 1970 s and early 1980 s. ${ }^{18}$ These records point to a widespread and catastrophic decrease in the Canadian prairie populations. This decrease was not uniform, however, and some localized leopard frog populations appear to be able to persist, despite an apparently decreasing regional population. ${ }^{19,20}$

What, then, is the current status of northern leopard frog populations in RMNP? The decline appears to have been slower than observed in areas outside the park, but may be still in progress. Again anecdotally, I observed leopard frogs relatively frequently prior to 2005 . Since that time, leopard frogs have been found less often, despite numerous revisits to the areas where they had previously been observed. However, the fact that they can still be found in a variety of areas of the park suggests that the population will persist for the time being.

\section{Conclusion and Recommendations}

As discussed above, while the methodologies do not allow us to determine actual population sizes, the information garnered from this survey does allow several conclusions to be drawn.

The first is that this survey has confirmed the trend first observed in 1987, in which it appears that Canadian toad populations have declined such that they are now considered to be extirpated from the park. It also confirms my personal observations that northern leopard frogs have declined in abundance, but these populations do not appear to be imminently threatened with extirpation. Finally, the survey also confirms the expansion of both the range and the abundance of gray treefrogs inside the park since 1987.

The following recommendations are suggested to provide further insight into the findings of this survey:

1. Following the completion of a review of the park's lake water quality, any changes in the physical and chemical makeup of 
RMNP water bodies should be examined for their possible negative effects on local frog or toad populations.

2. Following the development of standardized survey methods, amphibians in the park should be monitored every five years, starting in 2015.

\section{A multi-jurisdictional study of the current} Canadian toad population abundance and distribution across western Canada should be carried out to determine whether the apparent declines in RMNP are reflected in other areas.

\section{Acknowledgments}

I thank the RMNP staff for their frog sightings, and for making my return to university possible. Thanks also to $D$. Schock, P. Taylor, L. Thorpe, and M. Vassal, and an anonymous reviewer who reviewed early versions of this paper. Finally, I thank Rae, Katrien, Rebecca, and Abbey for their patience.

1. Anonymous (1974) List of Reptiles and Amphibians, Riding Mountain National Park. Indian and Northern Affairs, Catalogue No. R63-9874, Information Canada, Ottawa, ON.

2. CARCNET (2010) Canadian Amphibian and Reptile Conservation Network. Available at <http://www. carcnet.ca/english/amphibians/tour/amphCanada. php> (accessed 4 December 2010).

3. Collins $\mathrm{J}$ (2004) Where have all the frogs gone? Natural History 113:44-49.

4. Kendell K (2002) Survey Protocol for the Northern Leopard Frog. Alberta Sustainable Resource Development, Fish and Wildlife Division, Alberta Species at Risk Report No. 43, Edmonton, AB.

5. Munro SL (1987) Herpetile Field Survey Data Report, Riding Mountain National Park. Natural Resource Conservation, Prairie and Northern Region, Environment Canada. Winnipeg, MB.

6. Rempell J (2001) Recommendations for assessing northern leopard frog (Rana pipiens) populations within Riding Mountain National Park. Unpublished document, Brandon University, Brandon, MB.
7. Forsyth D (2002) Amphibian Monitoring to Detect Malformations in Newly Metamorphosed Frogs. Canadian Wildlife Service, Environment Canada, Edmonton, $\mathrm{AB}$.

8. Heyer WR, Donnelly MA, McDiarmid RW, Hayek LC, Foster MS (1994) Measuring and Monitoring Biological Diversity - Standard Methods for Amphibians. Smithsonian Institution Press, Washington, DC.

9. Dodd, CK (ed) (2009) Amphibian Ecology and Conservation: A Handbook of Techniques. Oxford University Press, Oxford.

10. Preston WB (1982) The Amphibians and Reptiles of Manitoba. Manitoba Museum of Man and Nature, Winnipeg, MB.

11. Cook FR (1984) Introduction to Canadian Amphibians and Reptiles. National Museums of Canada, Ottawa, ON.

12. Taylor $P$ (2008) Northward range extension for the gray treefrog in west-central Manitoba. Blue Jay 66:44-49.

13. Taylor $P$ (2009) An extension of treefrog range in Manitoba and into Saskatchewan. Blue Jay 67:235-241.

14. Sinkins P (2008) Ecological and hydrological consequences of beaver activity in Riding Mountain National Park, Manitoba. M.Sc. Thesis, University of Manitoba, Winnipeg, MB.

15. Environment Canada Weather Data. Available at <http://www.weatheroffice.gc.ca/city/pages/mb31_metric_e.html > (accessed 12 November 2010).

16. Mueller L, Harding J (2006) "Hyla versicolor." Animal Diversity Web. Available at <http:// animaldiversity.ummz.umich.edu/site/accounts/ information/Hyla_versicolor.html> (accessed 11 December 2010).

17. Bird R (1930) Biotic communities of the aspen parkland in central Canada. Ecology 11: 356-442.

18. Alberta Northern Leopard Frog Recovery Team (2005) Alberta Northern Leopard Frog Recovery Plan, 2005-2010. Alberta Species at Risk Recovery Plan No 7. Fish and Wildlife Division, Alberta Sustainable Resource Development, Edmonton, AB.

19. Bailey M (2004) Northern leopard frogs in a golf course water hazard. Blue Jay 62:43-45.

20. Schock DM, Bollinger TK (2005) An apparent decline of northern leopard frogs (Rana pipiens) on the Rafferty Dam mitigation lands near Estevan, SK. Blue Jay 63:144-154. 